\title{
Application of a modified method for stem cell isolation from lipoaspirates in a basic lab
}

\author{
Caroline T. Sardjono ${ }^{1,2}$, Melina Setiawan ${ }^{1}$, Frisca ${ }^{1}$, Virgi Saputra ${ }^{3}$, Gwendy Aniko ${ }^{4}$, Ferry Sandra ${ }^{1}$ \\ ${ }^{1}$ Stem Cell and Cancer Institute \\ ${ }^{2}$ Microbiology Department, Faculty of Medicine, Maranatha Christian University, Bandung, Indonesia \\ ${ }^{3}$ Kalbe Farma Tbk \\ ${ }^{4}$ Mitra Keluarga Kemayoran
}

\begin{abstract}
Abstrak
Tujuan Lipoaspirate mengandung jumlah sel punca mesenkimal yang banyak, sehingga lipoaspirate kini menjadi sumber sel punca mesenkimal yang sangat potensial bagi riset maupun untuk aplikasi klinis. Metode sederhana isolasi sel punca mesenkimal yang dapat diaplikasikan pada laboratorium dasar akan memfasilitasi perkembangan riset sel punca di negara berkembang. Diharapkan, hasil studi ini dapat meningkatkan pengembangan riset sel punca di Indonesia.

Metode Lipoaspirate dicerna dengan enzim collagenase type I kemudian dilakukan filtrasi. Pemurnian sel punca mesenkimal dilakukan dengan mengkultur sel selama 2-3 hari disusul dengan pembuangan supernatan. Konfirmasi populasi yang homogen dilakukan melalui analisis sel dengan metode flowcytometry sesuai dengan kriteria dari Mesenchymal and Tissue Stem Cell Committee of the International Society of Cell Therapy.

Hasil Sel punca mesenkimal yang dapat diperoleh dengan menggunakan prosedur ini adalah sebanyak 16,41 $\pm 8,22$ x $108 \mathrm{sel}$ per $120 \mathrm{ml}$ lipoaspirate. Sel hasil kultur menunjukan morfologi fibroblastik, sesuai dengan karakteristik sel punca mesenkimal dan berhasil dipurifikasi dari sel lainnya. Hal ini dikonfirmasi dengan analisis flowcytometry yang menunjukan ekpresi CD105, tanpa adanya ekspresi HLA-Class II, CD 45, CD 34, CD14, and CD19.
\end{abstract}

Kesimpulan Studi ini menunjukan bahwa sel punca mesenkimal dapat diisolasi dari lipoaspirate secara sederhana. Prosedur ini sangat memungkinkan untuk dilakukan di laboratorium dasar. (Med J Indones 2009; 18:91-6)

\begin{abstract}
Aim Lipoaspirate, a wasted by product from liposuction procedure recently has been shown to contain abundant mesenchymal stem cells (MSCs). MSCs have been studied in many research areas to regenerate many cell lineages including, myogenic, cardiomyogenic, and angiogenic lineages. The large quantity of MSCs in lipoaspirate, makes it an attractive source for stem cells used in research and clinical applications. A simplified method which is suitable to be performed in a basic laboratory will facilitate development of stem cell research in developing countries. Therefore the outcomes from this study are expected to encourage the progress of stem cell research in Indonesia.

Methods Lipoaspirate was digested using collagenase type I, followed by a basic filtration method. Purification of MSCs was done by cell culture for 2-3 days followed by supernatant removal. To confirm the homogenous population of MSCs, an analysis using flowcytometry was performed based on the MSCs minimal criteria developed by Mesenchymal and Tissue Stem Cell Committee of the International Society of Cell Therapy.

Resuts MSCs were able to be obtained at $16.41 \pm 8.22$ x 108 cells per $120 \mathrm{ml}$ lipoaspirate. The cultured cells showed fibroblastic morphology which is characteristic for MSCs and were able to be purified from non-MSCs cells. This was confirmed by flowcytometry assay showing expression of CD105 and the absence of HLA-Class II, CD 45, CD 34, CD14, and CD19.
\end{abstract}

Conclusions This study has shown that it was feasible to isolate messenchymal stem cell from human lipoaspirate. The procedure was practicable to be performed within a basic laboratory. (Med J Indones 2009; 18: 91-6)

Key words: mesenchymal stem cell, lipoaspirate, stem cell isolation technique 
Liposuction is one of the most popular cosmetic surgical procedures worldwide with an estimated one million liposuctions performed annually. ${ }^{1}$ Lipoaspirate, which often wasted as by product from liposuction procedure recently has been shown to contain abundant mesenchymal stem cells (MSCs). ${ }^{2}$

The use of lipoaspirate as a source for stem cells offers a far less invasive procedure for cell sampling than the aspiration of bone marrow. Moreover, the numbers of stem cells obtained from lipoaspirate are reportedly higher in lipoaspirate than its bone marrow counterpart. ${ }^{3}$ The average of MSCs occurrence in lipoaspirate was $1.2 \pm 0.3$ per 100 Adipose-derived Cells, much higher compared to $1 \mathrm{MSC}$ per 50,000 bone marrow nucleated cells. ${ }^{4}$

The clinical utilizations of MSCs from adipose tissue have been reported in the regenerative-reconstructive surgical procedures such as calvarial repair, tracheal repair, fistula healing in Crohn's disease, osteogenesis imperfecta, breast reconstructions, and tissue reconstruction of post-radiotherapy damage.$^{5-8}$ Recently, MSC therapies have been extended into treatment for cardiovascular diseases including acute myocardial infarction and chronic heart failure. ${ }^{9}$ Moreover, several types of medical device have been developed in order to fulfill the high demand of procedures that can cater quick isolation with high yield of MSCs from adipose tissue. ${ }^{6}{ }^{10}$ Moreover, there have been several providers offering an option for patients undergo liposuction to be able to store their stem cells in cryopreservation facility. ${ }^{11}$ This option allows the individuals to take benefits from their own stem cells for future applications.

Mesenchymal stem cells (MSCs), also known as marrow stromal cells or mesenchymal progenitor cells, are defined as self-renewable, multipotent progenitor cells with the capacity to differentiate into several distinct mesenchymal lineages. MSCs can be induced to differentiate into adipogenic, chondrogenic, and osteogenic linages in the laboratory using appropriate cocktails of growth factors and supplements (Figure 1). ${ }^{12}$ Furthermore, MSCs have been studied in many research area to regenerate cell linages including, myogenic, cardiomyogenic lines, and also differentiate into neurogenic, angiogenic and hepatic lineages..$^{10,13,14}$ Despite their capability to differentiate in vivo and in vitro into mesenchymal lineages, MSCs have also been shown to have an important role in the maintenance of haematopoiesis..$^{13}$

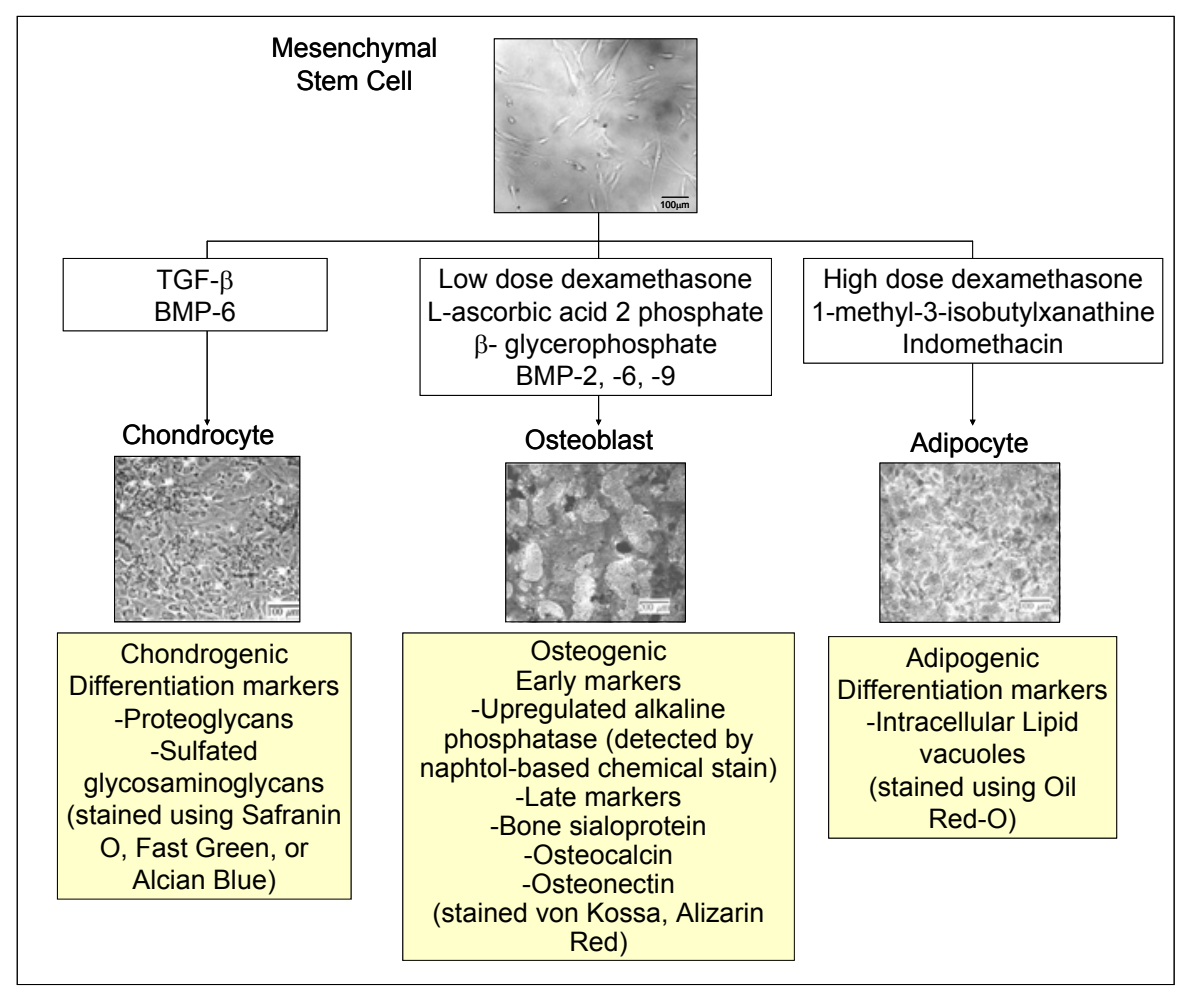

Figure 1. Multitineages differentiation of Mesenchymal Stem Cell (MSC) and additives used to stimulate cell differentiation 
Many publications have shown MSCs present and able to be isolated from many tissue types, such as bone marrow, trabecular bone, periosteum, synovial membrane, muscle, dermis, pericytes, blood, and adipose tissue. ${ }^{15-17}$ These demonstrate the potential of MSCs in addition to their plasticity and their usefulness in cell therapy. It is also of interest that neither autologous nor allogeneic MSCs induce any immunoreactivity in the host upon local transplantation or systemic administration. ${ }^{18,19}$ Finally, the large quantity of MSCs in lipoaspirates, makes it an attractive source for stem cells isolation for research and clinical applications. ${ }^{14,17}$ An optimized method which is suitable to be performed in a basic research laboratory clearly will facilitate development for basic laboratory to conduct stem cell research. Therefore the aim of this study was to modify the method of Zuk et al so that it would perform well in a minimal laboratory setting.

\section{METHODS}

\section{Mesenchymal stem cell isolation from lipoaspirates}

All protocols were reviewed and approved by the Stem Cell and Cancer Institute Institutional Review Board prior to the study (Proposal number 13/IRB/ $\mathrm{SCI} / \mathrm{KF} / 2008)$. Lipoaspirates were obtained with informed consent from individuals undergoing tumescent liposuction surgery in hospitals collaborated with Stem Cell and Cancer Institute. Lipoaspirates were stored at $2-8^{\circ} \mathrm{C}$ for no longer than 24 hours before they were used. Methods used to isolate the mesenchymal stem cells from lipoaspirate were adapted from methods in Zuk et al. ${ }^{17}$ The raw lipoaspirates $(120 \mathrm{ml})$ were diluted with equal volume of Phosphate Buffer Saline (PBS) and were divided evenly in 50ml-tubes (Figure 2 ). The diluted lipoaspirates were centrifuged at 430 $\times \mathrm{g}$ for 10 minutes continously at $20^{\circ} \mathrm{C}$. After centrifugation, the target cell-containing lipid phase was removed from the top and transferred in to new tubes and diluted with an equal volume of PBS. This washing step was repeated twice followed by further an equal volume dilution of cell-containing lipid fraction with pre-warmed $(37 \mathrm{oC}) 0.075 \%$ collagenase type I (Sigma) in PBS. Enzyme digestion was done by incubation at $37^{\circ} \mathrm{C}$ for 30 minutes on an orbital shaker (Figure 3 ). After digestion, enzyme activity was neutralized by adding equal volume of Dulbecco's modified Eagle's medium (DMEM) containing 10\% Fetal Bovine Serum (FBS). Digested product then subjected to centrifuga- tion at $600 \times \mathrm{g}$ for 10 minutes. Pellet was resuspended in DMEM with $10 \%$ PBS then filtered through a $100-\mu \mathrm{m}$ strainer mesh attached to a vacuum-pump to remove cellular debris (Figure 4). Collected cells after filtration were then ready for utilization. An aliquot was taken for cell count using hemocytometer under a light microscope to determined cell yields. Counts and viability were determined with a hemocytometer and the trypan blue dye exclusion technique. Briefly, $10 \mu 1$ trypan blue stock solution $(0.4 \% \mathrm{w} / \mathrm{v})$ was mixed with $10 \mu \mathrm{l}$ cells suspension, incubated for 3 minutes at room temperature then cells were counted in a hemocytometer chamber. With this method, dead cells appear blue and were therefore distinguishable from viable cells.

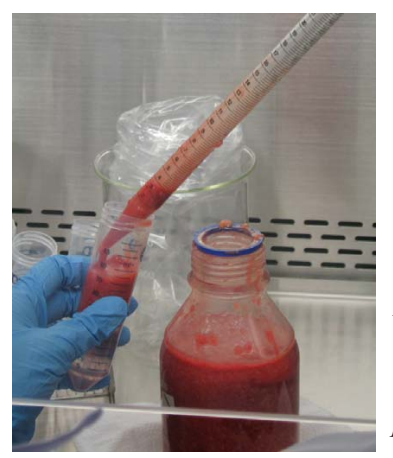

Figure 2. Procedure to dilute lipoaspirate by adding equal volume of Phosphate Buffer Saline (PBS) prior to the washing step

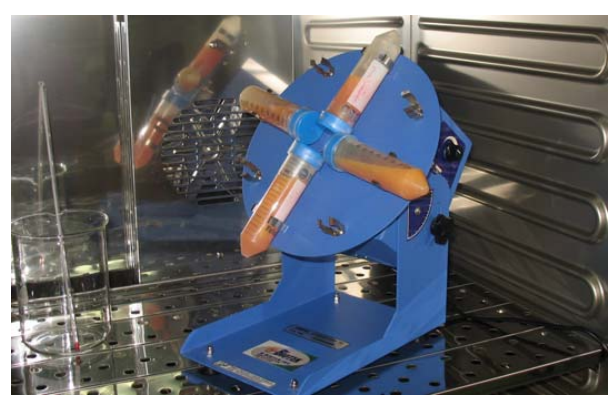

Figure 3. Procedure to isolate mesenchymal stem cells from lipoaspirate using collagenase was done by incubation at $37^{\circ} \mathrm{C}$ for 30 minutes on a rotating shaker

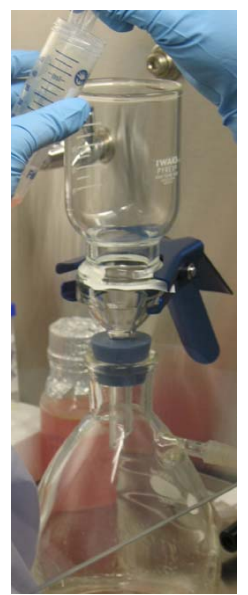

Figure 4. Filtration procedure by using a 100- $\mu \mathrm{m}$ strainer mesh attached to a vacuum pump to remove cellular debris 


\section{Mesenchymal stem cell culture}

The simplest technique to purify MSC from other contaminating cells was done by allowing the cells to adhere on plastic-surfaced disc. Cells were seeded at $1.3 \times 105 \mathrm{cells} / \mathrm{cm}^{2}$ in M-199 medium (Gibco 11150) supplemented with $20 \%$ Fetal Bovine Serum (Invitrogen 26140-079), $100 \mathrm{unit} / \mathrm{ml}$ penicillin and $0.1 \mathrm{mg} /$ $\mathrm{ml}$ streptomycin antibiotics (Sigma P0781), then kept in $37^{\circ} \mathrm{C}, 5 \% \mathrm{CO} 2$. After 2-3 days unwanted cells (nonMSC cells and debri) were removed by two washes with medium and expanded to reach $80 \%$ confluence. In another 6-7 days, adherent cells were detached using $0.25 \%$ trypsin EDTA solution (Sigma T4049), then M-199 medium $+20 \%$ FBS was used to inactivate trypsin. Detached cells with fibroblast-like morphology were cultured in another flask with cell density of $1.2 \times 105$ cells $/ \mathrm{cm}^{2}$ for 1 week or until confluence was achieved.

\section{Flowcytometry assay to determine MSC homog- enous population}

To confirm the simplified protocols were able to isolate good quality MSCs, several assays were conducted. MSCs have been known to express CD105 and deficient in the expression of HLA Class II, CD34 and CD45.

Expression HLA Class II molecules were determined using PE fluorescein conjugated monoclonal antibodies against HLA Class II (abcam 23901). Antibodies directed against CD45 were conjugated with FITC (BD 555482) and CD34 with FITC (BD 348053) incubated at $4 \mathrm{oC}$ in the dark for 15 minutes. Mouse IgG1-FITC (BD 349041) isotype matched negative controls were used to define background staining. The cells then analysed by flow analysis using FACSCalibur 3 argon laser 488nm (Becton Dickinson).

\section{RESULTS}

\section{Mesenchymal stem cell isolation and culture}

Using the methods described, MSCs were able to be obtained at $16.41 \pm 8.22 \times 108$ cells per $120 \mathrm{ml}$ lipoaspirate which have provided an abundant number of cells for further used (Table 1). The simplified method has proven to be gentle enough for the cells as shown by the high viability cells obtained (viable cells $92.57 \%$ $\pm 4.5 \%$ ).

Table 1. Lipoaspirate donors and cell yield

\begin{tabular}{cccc}
\hline Donor No. & $\begin{array}{c}\text { Lipoaspirate } \\
\text { volume }(\mathrm{ml})\end{array}$ & $\begin{array}{c}\text { Cell yield } \\
(\mathrm{x} \mathrm{10})\end{array}$ & $\begin{array}{c}\text { Viability } \\
(\%)\end{array}$ \\
\hline 1 & 120 & 4.27 & 90.05 \\
2 & 120 & 20.55 & 91.95 \\
3 & 120 & 22.2 & 89.16 \\
4 & 120 & 18.6 & 99.12 \\
\hline average & 120 & 16.405 & 92.57 \\
\hline
\end{tabular}

In cell culture, the isolated cells showed a fibroblast-like morphology which is characteristic for MSCs (Figure 5).

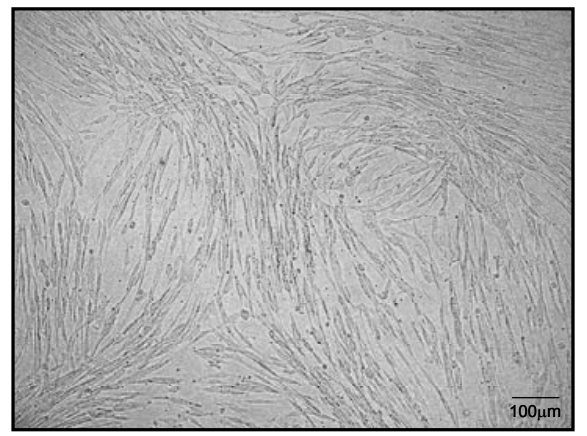

Figure 5. Homogenous MSCs showed fibroblast-like morphology during cell culture

\section{Flowcytometry analysis}

Cell surface molecules expressions were evaluated by flowcytometry assay on the harvested cell after a 14-day culture. Based on standard criteria for defining multipotent mesenchymal stem cells, we characterized the cultured cells by using several markers. MSCs should express CD105 (known as endoglin). CD105 is a type I membrane glycoprotein located on cell surfaces and is part of the TGF beta receptor complex. Moreover, the cultured cells should be excluded from the non-MSC cells most likely to be found in MSC cultures such as leukocytes (detected by CD45 expression), hematopoetic stem cells (expressing CD34), monocytes (expressing CD14), and B cell lymphocytes (CD19). HLA-DR (HLA Class II) molecules are not expressed on MSC unless stimulated, e.g. by IFN- $\gamma$. We confirmed our isolated and cultured cells were MSCs as they were mainly expressed CD105 and only a small proportion beared HLA-Class II, CD 45, CD 34, CD14, and CD19 (Figure 6). 


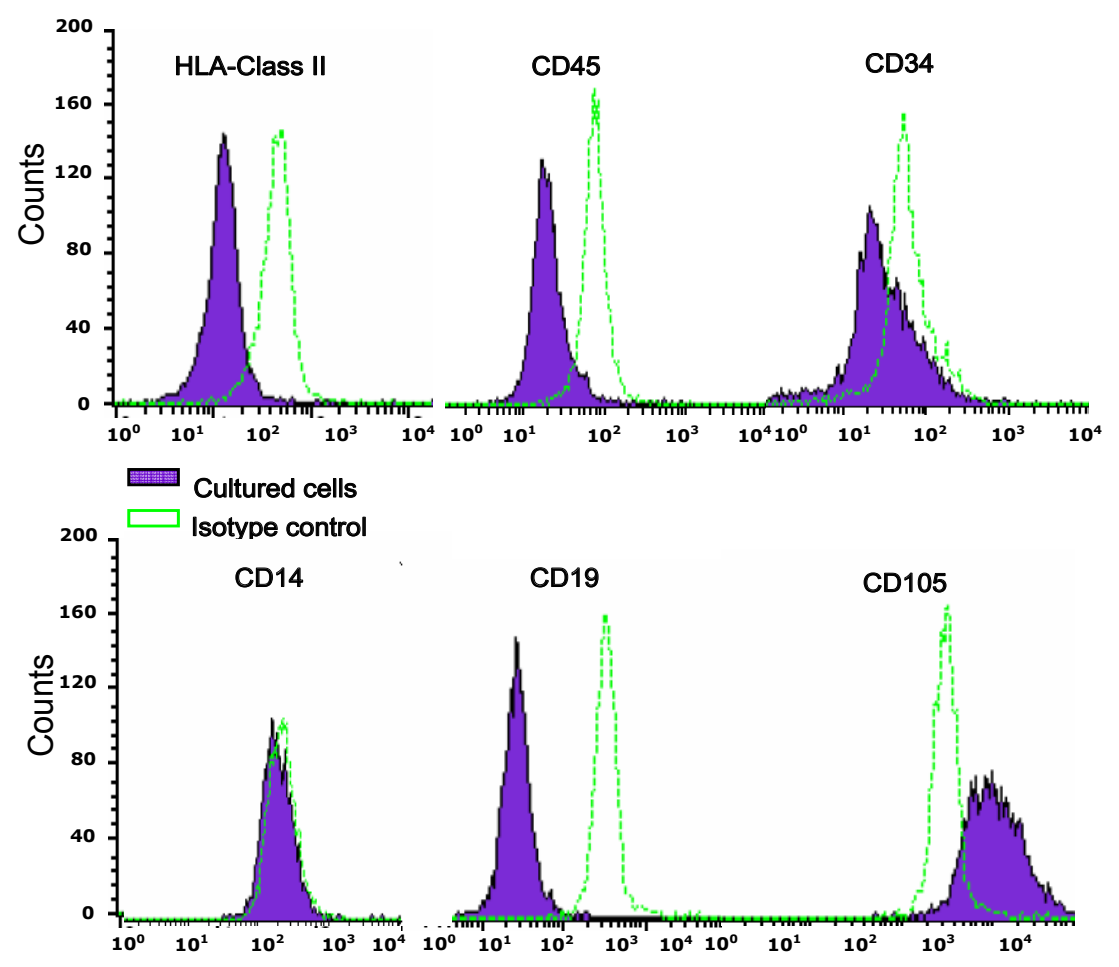

Figure 6. Flowcytometry analysis of molecules expression on MSC from lipoaspirate. Flowcytometry assay showed the cultured cells were consistent with the characteristic of MSCs, i.e. lacked of HLA class II expression, CD45, CD34, CD14 and CD19; with high expression of $C D 105$.

\section{DISCUSSION}

Stem cell research clearly is needed to be initiated in the developing countries including Indonesia. This is also due to the requirements to find a good strategy for stem cell as treatment in the regenerative medicine. Developing country has been getting an increase in the degenerative diseases cases each year. It is estimated by 2020,7 out of 10 deaths in developing countries will be attributable to non-communicable diseases 20. Moreover, developing countries now account for $80 \%$ of global cardiovascular disease-related deaths with twothirds of the 171 million people worldwide affected by diabetes reside in developing countries20. This report clearly has shown the urge for stem cell research to be conducted in Indonesia as soon as possible to support the progress in the stem cell-based therapy. The concern about starting a stem cell research also partly caused by the lack of experience in the possible modification of protocols for cell isolation, processing and analysis to suit the local laboratory conditions.

This study has demonstrated that it is possible to isolate mesenchymal stem cells from the lipoaspirate using a modification of Zuk's method. Lipoaspirate is truly rich with Mesenchymal Stem cell. Compared to the MSCs collected from bone marrow, the MSCs from lipoaspirate obviously is easier to obtain with the yields above the yield often found in the isolation of stem cell from bone marrow. Due to the unique property of MSCs, the international society for Mesenchymal and Tissue Stem Cell Committee of the ISCT ${ }^{21}$ proposes minimal criteria to define human MSCs. First, MSCs must be plastic-adherent when maintained in standard culture conditions. Second, MSCs express CD105, CD73, or CD90, and lack expression of CD45, CD34, CD14 or CD11b, CD79 $\alpha$ or CD19, or HLA-DR (HLA Class II). Third, MSCs should demonstrate their ability for trilineage mesenchymal differentiation i.e. should be able to differentiate into osteoblasts, adipocytes and chondroblasts using standard in vitro tissue culture-differentiating conditions. This study has been able to fulfill two out of the three criteria. A further study for MSCs differentiation using media and additives shown in Figure 1 would be done in a subsequent study.

Further purification of MSCs from unwanted cells such as white blood cells, endothelial cells, and smooth muscle cells, can be achieve using standard culture method 
using in plastic-surfaced discs. MSCs were identified as cell population with fibroblast-like morphology. ${ }^{21}$ The MSCs isolated from above protocol were able to be used in further experiments including differentiation into osteogenic, adipogenic, and chondrogenic progenitor cells. In this study, the flowcytometry assay was used to confirm that the cells were mainly CD105 bearing cells that were most likely MSC. This fact strongly suggests that the protocol is very well adapted and able to isolate nearly homogenous MSCs population in a minimal laboratory setting. For the application of this method in a circumstances where the experiments should be done without cell analysis equipments, another method such as detection of mRNA for CD105, CD73, or CD90, with the absence of CD34, CD 45 or HLA-DR (HLA Class II) can be pursued. It is important to notice though, that the grade of cells obtained using this method was designated to be used in research and should not be attempted for clinical uses.

This study has shown that by using simple equipments it was feasible to isolate messenchymal stem cell from human lipoaspirate an otherwise discarded material. The procedure was practicable to be performed within a basic laboratory with the good yield of cell. The outcomes from this study are expected to encourage the progress of stem cell research in Indonesia.

\section{Acknowledgements}

The authors wish to thank Prof. Santoso Cornain, dr, DSc. for sharing his invaluable expertise, to Boenjamin Setiawan, dr., PhD who delivered the idea of stem cell research, to the donors for donating their lipoaspirate, and the collaborated hospital staffs who have coordinated the material to be used in this study.

\section{REFERENCES}

1. Moseley TA, Zhu M, Hedrick MH. Adipose-derived stem and progenitor cells as fillers in plastic and reconstructive surgery. Plast Reconstr Surg. 2006;118(3 Suppl):S121-8.

2. Rebelatto CK, Aguiar AM, Moretao MP, Senegaglia AC, Hansen P, Barchiki F, et al. Dissimilar differentiation of mesenchymal stem cells from bone marrow, umbilical cord blood, and adipose tissue. Exp Biol Med. 2008;233(7):901-13.

3. Kern S, Eichler H, Stoeve J, Kluter H, Bieback K. Comparative Analysis of Mesenchymal Stem Cells from Bone Marrow, Umbilical Cord Blood, or Adipose Tissue Stem Cells. 2006;24:1294-1301

4. Fraser JK, Schreiber R, Strem B, Zhu M, Alfonso Z, Wulur I, et al. Plasticity of human adipose stem cells toward en- dothelial cells and cardiomyocytes. Nat Clin Pract Cardiovasc Med. 2006;3 Suppl 1:S33-7.

5. Meliga E, Strem BM, Duckers HJ, and Serruys PW. AdiposeDerived Cells. Cell Transplantation. 2007;16:963-70.

6. Garcia-Olmo D, Garcia-Arranz M, Herreros D, Pascual I, Peiro C, Rodriguez-Montes JA. A phase I clinical trial of the treatment of Crohn's fistula by adipose mesenchymal stem cell transplantation. Dis. Colon Rectum. 2005;48(7):1416-23.

7. Horwitz EM, Gordon PL, Koo WK, Marx JC, Neel MD, $\mathrm{McNall} \mathrm{RY}$, et al. Isolated allogeneic bone marrow-derived mesenchymal cells engraft and stimulate growth in children with osteogenesis imperfecta: Implications for cell therapy of bone. Proc. Natl. Acad. Sci. USA 2002;99:8932-7.

8. Yoshimura K, Matsumoto D, Gonda KA. Clinical trial of soft-tissue augmentation by lipoinjection with adiposederived stromal cells (ASCs). International Fat Applied Technology Society (IFATS). 2005;9-10.

9. Psaltis PJ, Zannettino A, Worthley SG, Gronthos S. Mesenchymal Stromal Cells - Potential for Cardiovascular Repair. Stem Cells. 2008;26(9):2201-10

10. Lin K, Matsubara Y, Masuda Y, Togashi K, Ohno T, Tamura $\mathrm{T}$, et al. Characterization of adipose tissue-derived cells isolated with the CelutionTM system. Cytotherapy. 2008;10(4):417-26.

11. Ilic D. Explores the latest developments in the field of stem cell research and regenerative medicine. Regenerative Medicine 2008;3(2):137-43.

12. Marion NW and Mao JJ. Mesenchymal Stem Cells and Tissue Engineering. In: Klimanskaya I and Lanza R, editors. Methods in enzymology. Pasadena, California: Elsevier; 2006. p. 339-61.

13. Alhadlaq A, Mao JJ. Mesenchymal Stem Cells: Isolation and Therapeutics. Stem cells develop. 2004; 13:436-48.

14. Meliga E, Strem BM, Duckers HJ, and Serruys PW. Adipose-Derived Cells. Cell Transplantation. 2007;16:963-70

15. Asakura A. Stem cells in adult skeletal muscle. Trends Cardiovasc Med 2003;13:123-8.

16. Belicchi M, Pisati F, Lopa R, Porretti L, Fortunato F, Sironi $\mathrm{M}$, et al. Human skin-derived stem cells migrate throughout forebrain and differentiate into astrocytes after injection into adult mouse brain. J Neurosci Res. 2004;77:475-86.

17. Zuk PA, Zhu M, Mizuno H, Huang J, Futrell W, Katz AJ et al. Multilineage cells from human adipose tissue: implications for cell-based therapies. Tissue Eng. 2001;7:211-28.

18. Le Blanc K dan Ringden. Immunobiology of human mesenchymal stem cells and future use in hematopoietic stem cell transplantation. Biology of Blood and Marrow Transplantation. 2005;11:321-4.

19. Yanez R, Lamana ML, García-Castro J, Colmenero I, Ramírez M, and Bueren JA. Adipose tissue-derived mesenchymal stem cells (ADMSCS) have in vivo immunosuppressive properties applicable for the control of the graft-versus-host disease. Stem Cells. 2006;24(11):2582-91.

20. Greenwood HL, Thorsteinsdottir H, Perry G, Renihan J, Singer PA, and Daar AS. Regenerative medicine: new opportunities for developing countries. Int. J. Biotechnology. 2006;8(12):60-77.

21. Dominici M, Le Blanc K, Mueller I, Slaper-Cortenbach I, Marini FC, Krause DS, et al. Minimal criteria for defining multipotent mesenchymal stromal cells. The International Society for Cellular Therapy position statement. Cytotherapy. 2006; 8(4), 315-7. 